\title{
Fruit characterization of 36 cape gooseberry hybrids for identification of potential industrial or fresh consumption uses
}

\section{Caracterización del fruto de 36 híbridos de uchuva para la identificación de su uso potencial industrial o de consumo en fresco}
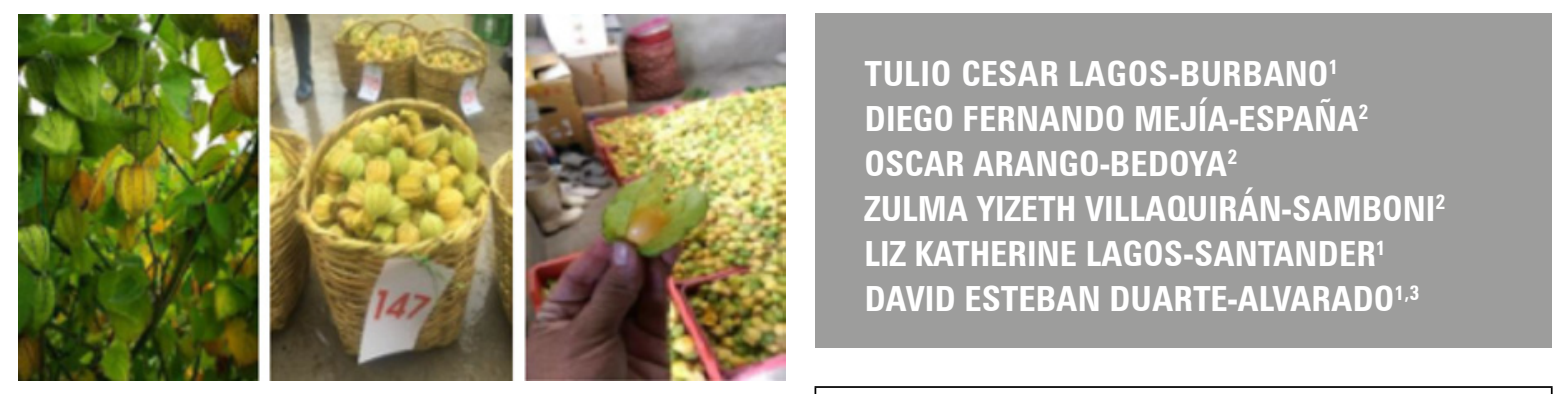

Cape gooseberry hybrid fruits.

Photos: D.E. Duarte-Alvarado

\begin{abstract}
The cape gooseberry is the second most exported fruit in Colombia. There are, however, little information available on genetic improvement processes and limited research on the fruit components. The objective of this study was to characterize the fruits of 36 hybrids, obtained from double haploid cape gooseberry lines from the Tibaitatá Research Center of the Colombian Corporation for Agricultural Research. Hybrids with potential uses in transformation processes or for fresh consumption were identified using Hierarchical Cluster (HC) and Principal Component Analysis (PCA) with 20 physical, physicochemical, compositional, and physiological fruit descriptors, obtained from four trials in the Andean region of southern Colombia. According to the PCA, three components represented $73.6 \%$ of the total variability: postharvest (37.5\%), sensory and nutritional quality $(21.3 \%)$ and cracking percentage (14.8\%). Six conglomerates were identified. Groups two, four, and six had aptitude for fresh consumption because of the size of the berry, high vitamin $\mathrm{C}$ content, maturity index and low cracking levels. Group one showed aptitude for processing and fresh consumption. Groups three and five registered a high seed content, low maturity rates, and a high cracking percentage.
\end{abstract}

\footnotetext{
Additional key words: Physalis peruviana; Andean crops; fruit maturation;
ascorbic acid; fruit cracking; genetic improvement; agroindustry.

Universidad de Nariño, Faculty of Agricultural Sciences, Grupo de Investigación en Producción de Frutales Andinos (GPFA), San Juan de Pasto (Colombia). ORCID Lagos-Burbano, T.C.: 0000-0001-9222-4674; ORCID Lagos-Santander, L.K.: 0000-0001-9932-0909; Duarte-Alvarado, D.E.: 0000-0002-8896-3594

Universidad de Nariño, Faculty of Agroindustrial Engineering, Grupo de Investigación Tecnologías Emergentes en Agroindustria (TEA), San Juan de Pasto (Colombia). ORCID Mejía- España, D.F.: 0000-0002-6707-5803; ORCID Arango-Bedoya, O.: 0000-0002-4693-2212; ORCID Villaquiran-Samboni, Z.Y.: 0000-0003-1456-0685

Corresponding author.deduartea@unal.edu.co
} 


\section{RESUMEN}

La uchuva es la segunda fruta más exportada de Colombia. Sin embargo, es poca la información disponible sobre los procesos de mejoramiento genético y son limitadas las investigaciones sobre los componentes del fruto. El objetivo de este trabajo fue caracterizar el fruto de 36 híbridos obtenidos a partir de líneas dobles haploides de uchuva del Centro de Investigación de Tibaitatá de la Corporación Colombiana de Investigación Agropecuaria. Se identificaron los híbridos que tienen potencial para ser útiles en procesos de transformación o para consumo en fresco, utilizando el Clúster Jerárquico (HC) y Análisis de Componentes Principales (ACP) con 20 descriptores físicos, fisicoquímicos, composicionales y fisiológicos del fruto, obtenidos en cuatro ensayos ubicados en la región Andina del sur de Colombia. Según el ACP, el 73,6\% de la variabilidad total fue representada por tres componentes: poscosecha (37,5\%), calidad sensorial y nutricional $(21,3 \%)$ y porcentaje de rajado $(14,8 \%)$. Se identificaron seis conglomerados. Los grupos dos, cuatro y seis, mostraron aptitud para el consumo en fresco debido al tamaño de la fruta, el alto contenido de vitamina $\mathrm{C}$, el índice de madurez y los bajos niveles de rajado. El grupo uno mostró aptitud para el procesamiento y el consumo en fresco. Los grupos tres y cinco registraron un alto contenido en semillas, un bajo índice de madurez $y$ un alto porcentaje de rajado.

Palabras clave adicionales: Physalis peruviana; cultivos Andinos; maduración de la fruta; ácido ascórbico; frutos rajados; mejora genética; agroindustria.

Received: 25-02-2021 Accepted: 14-03-2021 Published: 31-03-2021

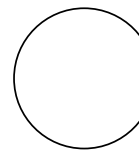

The cape gooseberry (Physalis peruviana L.) is the bestknown species of the Physalis genus, characterized by its high vitamin C, B3, and B6 contents, as well as high levels of carotenoids, phenolic compounds, flavonoids, tocopherols, fiber, and minerals, which have been recognized as health-promoting compounds (Ramadan, 2011). Colombia offers very suitable sites between 1,800 and 2,800 $\mathrm{m}$ a.s.l. for cape gooseberry cultivation (Fischer and Melgarejo, 2020) and is the world's leading producer of cape gooseberry, where the regional ecotype, known as Colombia, is characterized by adequate coloration and high sugar contents (Herrera et al., 2012). Germplasm collections exist in universities and research centers (Fischer et al., 2011) but they have not been thoroughly studied.

Partially characterized collections do exist, as well as a protocol to produce double haploid lines $(\mathrm{DH})$ or pure lines that reduce plant breeding times and produce new qualities (Sánchez et al., 2011). With this technique, the Colombian Agricultural Research Corporation (Agrosavia) has released the first variety, called Corpoica Dorada (Sánchez et al., 2016).

The use of statistical tools, such as Principal Component Analysis (PCA) and Hierarchical Classification $(\mathrm{HC})$, facilitates the identification of variability between genetic materials and allows them to be grouped according to a set of descriptors to expand information on existing and previously characterized materials that can then be used in breeding programs (Herrera et al., 2012).

Morillo et al. (2011) performed a morphological and molecular characterization of 18 cape gooseberry introductions from the collection of the Universidad de Nariño. PCA determined that fruit characteristics are most closely related in the P. peruviana variety. The classification analysis showed five clusters, grouped by soluble solids and calyx length. Herrera et al. (2012) evaluated the fruits of 54 cape gooseberry accessions from the germplasm bank of the Universidad Nacional de Colombia, from the central and north-eastern Andean region of Colombia, using 30 descriptors, 23 of which were quantitative. The first two components of the PCA were related to weight, fruit size, and titratable acidity. The $\mathrm{HC}$ generated two groups related to cultivated and undetermined genetic materials. This classification suggested the existence of a differential behavior in the metabolic maturation processes among the evaluated genetic materials.

García-Arias et al. (2018) evaluated 18 descriptors related to performance and fruit quality in a collection of 100 samples from Agrosavia. The results of the PCA showed that the traits related to fruit quality, 
such as size, cracking percentage, and firmness, contributed to the first component and could be useful in the selection stage in a plant breeding process.

Agrosavia has a large germplasm collection, which includes wild, native genotypes and new accessions or pure lines derived from the cultivation of anthers that include haploid and DH lines. According to Sánchez et al. (2011), the value of pure lines is evaluated in the production of hybrids for commercial purposes, which could support the sustainability and improvement of Colombian crops. However, at this time, the characterization of fruits from these hybrids has been carried out by only a few studies, which can be used in agro-industrial processes and as raw material in new genetic improvement programs. These programs have focused on the generation of new cultivars with good agronomic performance in agro-climatic regions that are suitable for the development of crops, where cape gooseberry production generates employment and collaboration among producers.

In a previous study, the physicochemical properties of fruits from 36 cape gooseberry hybrids were evaluated, and the materials with the highest fruit quality were selected with a selection index (Lagos-Burbano et al., 2020). In the present study, six new descriptors were included, aiming to classify or group the hybrids using PCA and HC analysis for potential uses in transformation processes or fresh consumption based on physical, physicochemical, compositional, and physiological characteristics.

\section{MATERIALS AND METHODS}

This study was conducted between the first semester of 2019 and the second semester of 2020 using fruits from 36 cape gooseberry hybrids that are crosses between nine $\mathrm{DH}$ lines from the Agrosavia collection. The 36 hybrids were evaluated in four specific environments in the high Andean zone of the Department of Nariño (Colombia). The environments included the municipalities of Ipiales $\left(0^{\circ} 52^{\prime} 53.32\right.$ " $\mathrm{W}, 77^{\circ} 33^{\prime} 58.2^{\prime \prime} \mathrm{N}$, at $2,900 \mathrm{~m}$ a.s.1., $14^{\circ} \mathrm{C}$ and $75 \%$ relative humidity - $\mathrm{RH})$; Gualmatán (054'48.21" $\mathrm{W}, 77^{\circ} 34^{\prime} 05.76^{\prime \prime} \mathrm{N}$, at $2,830 \mathrm{~m}$ a.s.1., $13^{\circ} \mathrm{C}$ and $70 \%$ $\mathrm{RH})$; Puerres ( $0^{\circ} 54^{\prime} 20.53^{\prime \prime} \mathrm{W}, 77^{\circ} 28^{\prime} 33.52^{\prime \prime} \mathrm{N}$, at 3,016 $\mathrm{m}$ a.s.1., $12^{\circ} \mathrm{C}$ and $\left.72 \% \mathrm{RH}\right)$ and Pasto $\left(01^{\circ} 11^{\prime} 48.65^{\prime \prime}\right.$ $\mathrm{W}, 77^{\circ} 18^{\prime} 13.17^{\prime \prime} \mathrm{N}$, at $2,746 \mathrm{~m}$ a.s.l., $18^{\circ} \mathrm{C}$ and $67 \%$ $\mathrm{RH})$. The experiment design used randomized complete blocks, repeated four times; each experiment plot corresponded to a groove of five plants. LagosBurbano et al. (2020) presented a detailed description of the field experiment.

The following traits were evaluated in $1 \mathrm{~kg}$ of fruits in stages four and five of maturity according to the color table established in Colombian Technical Standard NTC 4580 (Icontec, 1999): the fruit weight was recorded with calix (FWC) and without calyx (FWWC) in 30 fruits taken at random from a $1 \mathrm{~kg}$ sample. The equatorial diameter (ED) and polar axis were determined (PE) using a Discover caliper with $\pm 0.05 \mathrm{~mm}$ accuracy, and the fruit volume (VF) was recorded using a $100 \mathrm{~mL}$ graduated cylinder and water displacement. The dry weight (DW) was expressed as a percentage according to the AOAC 930.15 method (AOAC, 1990). The seed weight per fruit (WS) was determined using seeds extracted from 10 randomly selected fruits, with which the weight of 200 seeds (W200) and the number of seeds per fruit (NSF) were also obtained. The hydrogen potential of the juice $(\mathrm{pH})$ was measured with a WTW $720 \mathrm{pH}$ meter (inoLab, Weilheim, Germany), and the juice color index (JCI) and fruit color index (FCI) were determined with a CM5 spectrophotometer (Konica Minolta, Osaka, Japan) in the CIE-Lab color space using equation 1 (Vignoni et al., 2006)

$\mathrm{CI}=\left(1,000 \times a^{*}\right) /\left(L^{*} \times b^{*}\right)$

where, $a^{*}$ is chromaticity from green to red, $b^{*}$ is chromaticity from blue to yellow, and $L^{*}$ is luminosity.

Data on the following variables were used to perform the PCA and identify hybrids whose fruits have potential uses for fresh consumption or industrial processing: cracking percentage $(\mathrm{CP})$, which is the number of fruits showing this defect out of 50 randomly picked fruits; juice content (JC), which is the mean volume of juice extracted from 15 random fruits; total titratable acidity (TTA), measured with titration using 0.1 $\mathrm{N} \mathrm{NaOH}$ and expressed as a percentage of citric acid; total soluble solids (TSS), determined using a refractometer and expressed as ${ }^{\circ}$ Brix; maturity index (MI), which is the relationship between TSS and TTA; respiration rate (RR), obtained with an GC-2028 $\mathrm{CO}_{2}$ analyzer (Lutron Electronic Enterprise Co., Ltd., Taipei, Taiwan) by placing approximately $100 \mathrm{~g}$ of fruit without calyx in a tightly closed glass container with a sensor for $10 \mathrm{~min}$ to take readings, expressed in $\mathrm{mg}$ $\mathrm{CO}_{2} \mathrm{~kg}^{-1} \mathrm{~h}^{-1}$; Ascorbic acid content (AA), determined with a Reflectoquant ROflex 20 reflectometer (Merck KGaA, Darmstadt, Germany), according to the manufacturer's instructions and expressed in $\mathrm{mg} / 100$ 
g juice; and fruit firmness, (F) measured using an FT 327 manual penetrometer (Facchini SRL, Alfonsine, Ravenna, Italy) with a $5 \mathrm{~mm}$ diameter tip that was introduced into the surface of ten fruits without epidermis transversely to the peduncular scar. These variables were evaluated and discussed in a previous study by Lagos-Burbano et al. (2020).

The averages of the quantitative traits were used for the principal component analysis (PCA). For this procedure, the coefficient of variation (CV) was first calculated, then those variables with a CV below 3\% were discarded from the PCA, as recommended by Yazdanpour et al. (2018), who indicated that descriptors with a high CV differentiate genetic materials with a higher confidence level. Subsequently, the hierarchical cluster (HC) analysis was performed using the Ward method with Euclidean distances calculated prior to data normalization to arrange the 36 hybrids according to the variables used in the PCA.A Tukey test was applied to detect significant differences between the means of each cluster with $P<0.05$. The analyses were performed with SAS 9.4 (SAS Institute Inc., Cary, NC, USA).

\section{RESULTS AND DISCUSSION}

To carry out the PCA of the twenty traits, those with coefficients of variation greater than $3.1 \%$ were selected: CP, FWC, FWWC, VF, JC, WS, NSF, TTA, MI, $\mathrm{RR}, \mathrm{AA}, \mathrm{F}, \mathrm{JCI}$, and FCI. The six remaining descriptors were discarded: ED, PE, DW, W200, pH, and TSS.

The PCA resulted in the grouping of the 14 selected variables into three main components, which explained $73.6 \%$ of the total variation (Tab. 1).

The first principal component (PC1) accounted for $37.5 \%$ of the total variability. This component was mainly determined by variables related to size (FWC, FWWC and FV), seeds (WS), and firmness, with positive variable factor (rv-f) correlations between 0.30 and 0.37 (Tab. 1). PC1 could be called the "postharvest quality component" because grouped large fruits with high firmness values that would be suitable for long-term storage.

The second principal component (PC2) explained $21.3 \%$ of the variability and was determined by

Table 1. Principal Component Analysis (PCA) and correlation of 14 traits versus the first three principal components (PC) for 36 hybrids between nine double haploid lines of $P$. peruviana.

\begin{tabular}{|c|c|c|c|}
\hline Variance explained & $\mathrm{PC}_{1}$ & $\mathrm{PC}_{2}$ & $\mathrm{PC}_{3}$ \\
\hline Eigenvalue & 5.24 & 2.98 & 2.08 \\
\hline Proportion of total variance cumulated (\%) & 37.5 & 21.3 & 14.8 \\
\hline Variance cumulated (\%) & 37.5 & 58.7 & 73.6 \\
\hline Traits & $\mathrm{PC}_{1}$ & $\mathrm{PC}_{2}$ & $\mathrm{PC}_{3}$ \\
\hline Cracking porcentaje (CP) & 0.17 & -0.20 & 0.45 \\
\hline Fruit fresh weight with calyx (FWC) & 0.37 & 0.29 & -0.05 \\
\hline Fruit fresh weight without calyx (FWWC) & 0.34 & 0.34 & -0.07 \\
\hline Fruit volume (VF) & 0.36 & 0.30 & -0.09 \\
\hline Juice content (JC) & 0.27 & 0.39 & 0.03 \\
\hline Weight of seeds per fruit (WS) & 0.33 & -0.17 & -0.35 \\
\hline Number of seeds per fruit (NSF) & 0.27 & -0.17 & -0.43 \\
\hline Acidity (TTA) & 0.29 & -0.37 & -0.01 \\
\hline Maturity index (MI) & -0.27 & 0.31 & -0.23 \\
\hline Respiration rate (RR) & 0.03 & -0.16 & -0.28 \\
\hline Ascorbic acid (AA) & -0.09 & 0.40 & 0.14 \\
\hline Firmness (F) & 0.30 & -0.20 & 0.17 \\
\hline Juice color index (JCI) & -0.24 & 0.08 & -0.19 \\
\hline Fruit color index (FCI) & -0.17 & -0.05 & -0.51 \\
\hline
\end{tabular}

$\mathrm{PC}=$ principal component. 
FWWC, VF, JC, MI, and AA, with positive rv-f values between 0.30 and 0.40 and negative values in TTA $(-0.37)$. This component grouped hybrids that, because of the size, maturity, and vitamin $C$ content would be good options for fresh consumption, leading to the label "sensory and nutritional quality". The third component (PC3) explained 14.8\% of the existing variability and was influenced by $\mathrm{CP}$, contributing 0.45 to the factor, and seed content (WS) and FCI, with rv-f values between -0.35 and -0.51 . Therefore, this component was deemed "susceptibility to cracking percentage."

Since CP is unacceptable for fresh fruit consumption, the hybrids grouped in the positive axis of this variable could be used in industrial processing, provided they are not affected by fungi or bacteria. Morillo et al. (2011) found that the variables of weight, diameter, polar axis, number and weight of seeds and soluble solids determined conformation in the first three components when evaluating 18 cape gooseberry introductions, indicating the importance of these traits for the characterization of cape gooseberry variability. Singh et al. (2013) found similar results, demonstrating that fruit weight, length, and diameter contributed positively to the conformation of the first component in 20 different cape gooseberry genotypes. Herrera et al. (2012) also reported that variables related to physical aspects of fruits in 54 cape gooseberry accessions such as weight, volume and diameter, maturity index and $\mathrm{pH}$ contributed to conformation in the first component, while maturity index, $\mathrm{pH}$, soluble solids, cracking, acidity, and firmness contributed to the second, retaining between $52.42 \%$ of the total variability. García-Arias et al. (2018) found that variables associated with fruit size, cracking percentage and firmness accounted for $63 \%$ of the observed variation. The instant results are consistent with previous studies because they show that traits related to size and physicochemical characteristics are more discriminating, therefore making a greater contribution to variability in quality-related parameters in cape gooseberry fruits.

The Hierarchical Classification Analysis based on the traits used in the PCA determined the conformation of six groups at a distance of 7.0 (Fig. 1). It should be noted that the RR trait did not show significant differences between the groups.

The first cluster was made up of five hybrids, representing $14 \%$ of the cultivars (Tab. 2). These hybrids were characterized by their capacity to generate large fruits with high juice and vitamin $\mathrm{C}$ contents. FWC, FWWC, JC, and VF averages that were statistically higher than the fourth group were also recorded, along with an average AA content that was higher than in groups 4 and 5 . In addition, this cluster registered significantly lower means for seed content (WS and NSF) and FCI than in groups 2, 3, 5 and 2, 3, 4, and 6 , respectively. CP showed no significant differences with the other groups. These hybrids showed aptitude for both industrial processing because of the high juice content (between 63.0 and $69.3 \%$ of the

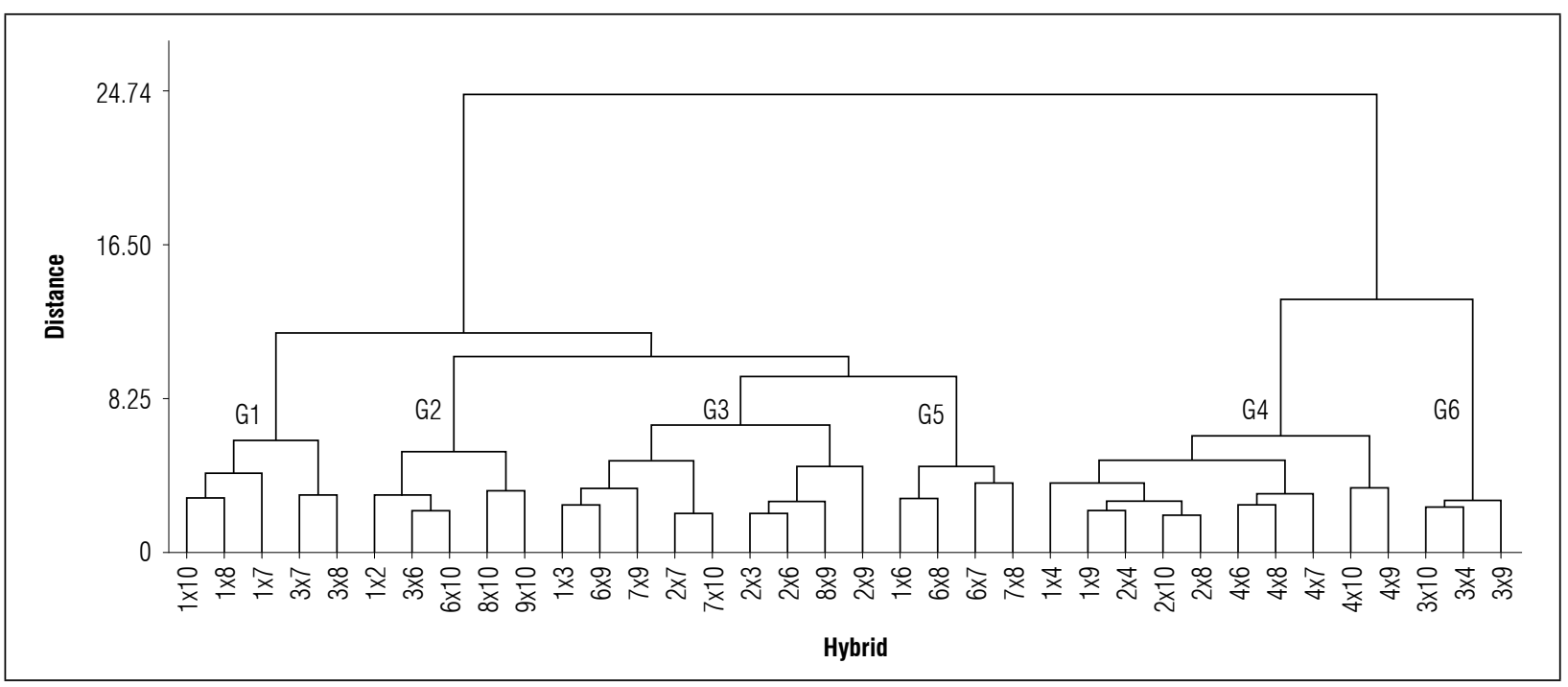

Figure 1. Dendrogram of Hierarchical Classification Analysis for $\mathbf{3 6}$ hybrids between nine double haploid $P$. peruviana lines. 
fresh weight) and low seed content (4.45-5.04\%) and for fresh consumption because of the high vitamin $\mathrm{C}$ content (38.41-42.00 mg/100 g of pulp).

The second group contained five hybrids and presented the highest averages for the traits related to fruit size (FWC, FWWC, VF), which were statistically higher than in groups $3,4,5$, and 6 . In addition, this group showed high averages for JC, higher than the fourth cluster. The second cluster also grouped the hybrids with the highest seed content, with statistically higher averages than groups 1,4 , and 6 , and a significantly higher FCI than in clusters 1 and 5 . The CP values for these hybrids was significantly lower than the fifth cluster. The low CP percentage (between $22.21 \%$ and $38.75 \%$ ) demonstrated the potential for fresh consumption, while the high seed content (between 5.01 and $5.56 \%$ of fresh weight) makes it suitable for potential use with oil extraction technology, presenting a dietary source of natural antioxidants (Chasquibol and Yácono, 2015). Additionally, this by-product can be used in products such as jams because, as some authors have confirmed, they increase nutritional value (Pérez-Herrera et al., 2019).
The third group had $25 \%$ of the genetic materials (nine hybrids), characterized by high averages for the seed content (WS, NSF) and high acidity percentages (higher than groups 1, 4, and 6) and maturity indexes (lower than the sixth group). High rates for fruit and juice color were also identified (higher than groups 1 and 5). The average FCI was the highest among the six groups. For this cluster, there were no significant differences in the $\mathrm{CP}$ from the remaining groups. Although these fruits visually showed optimum maturity coloration according to the FCI, the physicochemical maturity index showed that the sensory characteristics of these materials were not the best for fresh consumption. However, high FCIs were likely the result of a rapid accumulation of carotenoids (Balaguera-López et al., 2014), antioxidant agents that protect lipids from peroxidation. Therefore, direct consumption would be the best way to take advantage of these compounds although it is possible to use these genetic materials as bio functional ingredients in different products, such as beverages (Ramadan et al., 2013), emulsions (Ramírez-Nieto et al., 2019), and purees (Málaga et al., 2013), etc. In addition, the relatively high seed content (between 5.20 and 5.60 $\%$ of the fresh weight) reflected the potential of these

\section{Table 2. Averages per cluster of Hierarchical Classification Analysis for 14 traits evaluated in 36 hybrids from nine double} haploid $P$ peruviana lines.

\begin{tabular}{|c|c|c|c|c|c|c|c|}
\hline \multirow{2}{*}{ Traits } & \multicolumn{6}{|c|}{ Cluster } & \multirow{2}{*}{$\begin{array}{l}\text { General } \\
\text { average }\end{array}$} \\
\hline & 1 & 2 & 3 & 4 & 5 & 6 & \\
\hline Cracking percentage (\%) & $41.20 a b$ & $31.60 \mathrm{~b}$ & $40.76 a b$ & $31.13 b$ & 56.31 a & $30.29 b$ & 37.73 \\
\hline Fruit weight with calyx (g) & $6.80 \mathrm{ab}$ & $7.09 \mathrm{a}$ & $6.62 b$ & $6.26 \mathrm{c}$ & $6.65 b$ & 6.44 bc & 6.60 \\
\hline Fruit weight without calyx (g) & $6.09 a b$ & $6.31 \mathrm{a}$ & $5.87 \mathrm{~b}$ & $5.55 c$ & $5.87 \mathrm{~b}$ & $5.78 \mathrm{bc}$ & 5.86 \\
\hline Fruit volume (mL) & $5.84 a b$ & $6.03 \mathrm{a}$ & 5.64 bc & $5.33 d$ & $5.61 \mathrm{bcd}$ & $5.45 \mathrm{~cd}$ & 5.62 \\
\hline Juice content (mL) & $4.07 \mathrm{a}$ & $4.11 \mathrm{a}$ & $3.83 a b$ & $3.65 b$ & $3.86 a b$ & $3.93 \mathrm{ab}$ & 3.86 \\
\hline Weight of seeds per fruit $(\mathrm{g})$ & 0.28 bc & $0.33 \mathrm{a}$ & $0.32 \mathrm{a}$ & $0.30 \mathrm{~b}$ & $0.32 \mathrm{a}$ & $0.26 \mathrm{c}$ & 0.30 \\
\hline Number of seeds per fruit & $261.49 b$ & $297.6 \mathrm{a}$ & 290.67 a & $272.86 \mathrm{~b}$ & $289.25 \mathrm{a}$ & $260.17 b$ & 279.94 \\
\hline Respiration rate $\left(\mathrm{mg} \mathrm{CO}_{2} \mathrm{~kg}^{-1} \mathrm{~h}^{-1}\right)$ & 52.77 a & 56.87 a & 53.27 a & $55.40 \mathrm{a}$ & 53.74 a & 49.81 a & 54.05 \\
\hline Ascorbic acid $(\mathrm{mg} / 100 \mathrm{~g})$ & $40.54 \mathrm{a}$ & $39.97 \mathrm{ab}$ & $39.99 a b$ & $38.72 b$ & $38.34 b$ & $41.97 \mathrm{a}$ & 39.69 \\
\hline Firmness (N) & $8.24 a b$ & $8.31 \mathrm{ab}$ & $8.25 a b$ & $8.05 a b$ & $8.49 a$ & $7.83 \mathrm{~b}$ & 8.19 \\
\hline Juice color index & $6.91 \mathrm{ab}$ & $6.80 \mathrm{ab}$ & $7.11 \mathrm{a}$ & $7.13 \mathrm{a}$ & $6.40 \mathrm{~b}$ & $7.34 \mathrm{a}$ & 6.99 \\
\hline Fruit color index & $6.67 \mathrm{~b}$ & $7.07 \mathrm{a}$ & $7.16 \mathrm{a}$ & $7.11 \mathrm{a}$ & $6.68 \mathrm{~b}$ & $7.08 \mathrm{a}$ & 7.00 \\
\hline Acidity (citric acid, \%) & $2.02 b$ & $2.04 a b$ & $2.08 \mathrm{a}$ & $2.02 b$ & $2.10 \mathrm{a}$ & $1.86 \mathrm{c}$ & 2.03 \\
\hline Maturity index & $7.41 \mathrm{ab}$ & $7.43 \mathrm{ab}$ & $7.34 b$ & $7.45 a b$ & $7.20 \mathrm{~b}$ & $7.85 \mathrm{a}$ & 7.42 \\
\hline Number of hybrids in the cluster & 5 & 5 & 9 & 10 & 4 & 3 & \\
\hline Cluster participation (\%) & 14 & 14 & 25 & 28 & 11 & 8 & \\
\hline
\end{tabular}

Means with different letters indicate significant differences according to Tukey's test $(P<0.05)$. 
hybrids in the extraction of oil or in the production of products such as jams, as mentioned above. Studies, such as by Fischer et al. (2007), stated that the characteristics number of seeds per fruit and fruit weight correlate with altitude and genotype, obtaining higher percentages at lower altitudes and vice versa.

The fifth group had $11 \%$ of the hybrids, presenting the highest CP averages (significantly higher than groups 2,4 , and 6) and a high seed content (WS, NSF), with a statistically higher average than in groups 1,4 , and 6 . The highest firmness averages and the lowest maturity rates were found in this cluster. In both cases, the average was statistically different from the sixth group. This group had the highest averages of acidity and the lowest recorded vitamin $\mathrm{C}$, with statistical differences from groups 1, 4, and 6 for TTA and 1 and 6 for AA. Also, this group presented the lowest juice color indices (lower than groups 3,4 , and 6 ) and low fruit color indices (lower than in clusters 2, 3, 4, and 6). The high seed content in this group (between 5.27 and $5.73 \%$ of the fresh weight), high CP percentage (between 35.25 and $71.88 \%$ ), low maturity index (between 6, 88, and 7.50), and reduced vitamin $C$ content (from 37.73 to $39.0 \mathrm{mg} / 100 \mathrm{~g}$ of pulp) showed that these fruits are not suitable for fresh consumption. Therefore, as with the third cluster, they could be used for industrial processing.

The $19 \%$ of the materials were in groups 4 and 6 , with low average CP percentages, fruit sizes, seed contents, acidity, and firmness, along with high maturity rates and juice color. However, group 4, consisting of four hybrids, showed lower vitamin $C$ and juice contents and smaller fruit sizes and volumes than in group 6, with a significantly lower average AA than in groups 1 and 6 . The JC was lower than in groups 1 and 2, the FWC and FWWC were lower than in groups 1, 2, 3, and 5, and the VF was lower than in groups 1,2 , and 3 . The lowest averages for fruit size (FWC, FWWC and VF) and juice content were observed in the fourth cluster. Although the fruits in this cluster were the smallest (FWC from 5.90 to $6.56 \mathrm{~g}$ ), the low seed content (between 5.17 and $5.44 \%$ of fresh weight) and CP (24.88 to $48.50 \%)$ mean they can be used for fresh consumption.

On the other hand, the reduced juice content (between 63.64 and $67.57 \%$ of the fresh weight) could limit use in transformation processes that involve juice (juices, nectars). It should be noted that the fourth group had seven of the eight hybrids from the fourth-line, representing $70 \%$ of the hybrids in this group. Therefore, traits such as small fruit sizes and low vitamin $C$ contents could characteristic of this genotype. The sixth group showed the lowest values for CP, firmness, acidity, and seed content, as well as the highest maturity indices, juice color and vitamin $\mathrm{C}$ content. The CP and F levels were statistically lower than in the fifth group, the NSF was lower than in groups 2, 3 and 5 , the AA was higher than in groups 4 and 5 , the JCI was higher than in the fifth group, and the MI was higher than in groups 3 and 5 .

Additionally, the sixth cluster was characterized by an average seed weight per fruit (WS) that was significantly lower than in groups $2,3,4$, and 5 and the general average. This group also had an average acidity (TTA) that was significantly lower than the general average and the average of the remaining clusters.

The low CP (26.75 to $35.75 \%$ ), together with the higher maturity rates (7.72 to 7.93 ), juice content (66.61 to $70.48 \%$ fresh weight), and vitamin C (41.01 to $42.59 \mathrm{mg} / 100 \mathrm{~g}$ of pulp), made the sixth group the best in terms of sensory and nutritional characteristics. Therefore, the hybrids of this group are the most suitable for fresh consumption in the shortest time possible, given the low levels of firmness, or for processing using techniques that do not alter the content of antioxidant compounds in the fruit, such as lyophilization (Cortés et al., 2015).

\section{CONCLUSIONS}

The Principal Components Analysis showed that the traits related to physical (size, cracking percentage, color, firmness), compositional (seeds, juice) and physicochemical characteristics (maturity index, vitamin C) contributed to conformation in the first three components, explaining $73.6 \%$ of the total population variability, which consisted of 36 cape gooseberry hybrids.

The evaluation with the Hierarchal Classification Analysis grouped the hybrids into six clusters, detecting the existence of promising hybrids for fresh consumption, industrial processing, and secondary transformation processes.

\section{ACKNOWLEDGMENTS}

The authors thank the Universidad de Nariño, Gobernación de Nariño and Sistema General de Regalías for funding this study. 
Conflict of interests: The manuscript was prepared and reviewed with the participation of the authors, who declare that there exists no conflict of interest that puts at risk the validity of the presented results.

\section{BIBLIOGRAPHIC REFERENCES}

AOAC, Association of Official Analytical Chemists. 1990. Official methods of analysis of the Association of Official Analytical Chemists. $15^{\text {th }}$ ed. Arlington, TX.

Balaguera-López, H.E., C.A. Martínez, and A. Herrera-Arévalo. 2014. Papel del cáliz en el comportamiento poscosecha de frutos de uchuva (Physalis peruviana L.) ecotipo Colombia. Rev. Colomb. Cienc. Hortic. 8(1), 181-191. Doi: 10.17584/rcch.2014v8i2.3212

Chasquibol, N. and J.C. Yácono. 2015. Composición fitoquímica del aceite de las semillas del fruto de "aguaymanto", Physalis peruviana L. Rev. Soc. Quím. Perú 81(1), 311-318. Doi: 10.37761/rsqp.v81i4.36

Cortés, G.M., G.A. Prieto, and W.E. Rozo. 2015. Caracterización bromatológica y fisicoquímica de la uchuva (Physalis peruviana L.) y su posible aplicación como alimento nutracéutico. Cienc. Desarro. 6(1), 87-97. Doi: 10.19053/01217488.3653

Fischer, G., A. Herrera, and P.J. Almanza. 2011. Cape gooseberry (Physalis peruviana L.). pp. 374-396. In: Yahia, E.M. (ed.). Postharvest biology and technology of tropical and subtropical fruits. Woodhead Publishing Limited, Oxford, UK. Doi: 10.1533/9780857092762.374

Fischer, G., G. Ebert, and P. Lüdders. 2007. Production, seeds and carbohydrate contents of cape gooseberry (Physalis peruviana L.) fruits grown at two contrasting Colombian altitudes. J. Appl. Bot. Food Qual. 81, 29-35.

Fischer, G. and L.M. Melgarejo. 2020. The ecophysiology of cape gooseberry (Physalis peruviana L.) - an Andean fruit crop. A review. Rev. Colomb. Cienc. Hortic., 14(1), 76-89. Doi: 10.17584/rcch.2020v14i1.10893

García-Arias, F.L., J.A. Osorio-Guarín, and V.M. Núñez. 2018. Association study reveals novel genes related to yield and quality of fruit in cape gooseberry (Physalis peruviana L.). Front. Plant Sci. 9(1), 362. Doi: 10.3389/ fpls.2018.00362

Herrera, A., G. Fischer, and M.I. Chacón. 2012. Agronomical evaluation of cape gooseberries (Physalis peruviana L.) from central and north-eastern Colombia. Agron. Colomb. 30(1), 15-24.

Icontec, Instituto Colombiano de Normas Técnicas y Certificación. 1999. NTC 4580: Frutas frescas. Uchuva. Especificaciones. Bogota.

Lagos-Burbano, T.C., D.F. Mejía-España, O. Arango-Bedoya, Z.Y. Villaquirán-Samboni, L.K. Lagos-Santander, and D.E. Duarte-Alvarado. 2020. Physicochemical properties of Colombian cape gooseberry hybrids in the selection of high-quality materials. Pesq. Agropec.
Bras. 55, e01905. Doi: 10.1590/s1678-3921.pab2020. v55.01905

Málaga, R., A. Guevara, and M. Araujo. 2013. Efecto del procesamiento de puré de aguaymanto (Physalis peruviana L.), sobre los compuestos bioactivos y la capacidad antioxidante. Rev. Soc. Quím. Perú 79(1), 162-174.

Morillo, A.T., D.E. Villota, T.C. Lagos, and H.R. Ordóñez. 2011. Caracterización morfológica y molecular de 18 introducciones de uchuva Physalis peruviana L. de la colección de la Universidad de Nariño. Rev. Fac. Nac. Agron. Medellin 64(1), 6043-6053.

Pérez-Herrera, A., G.A. Martínez-Gutiérrez, F.M. León-Martínez, and M.A. Sánchez-Medina. 2019. The effect of the presence of seeds on the nutraceutical, sensory and rheological properties of Physalis spp. fruits jam: a comparative analysis. Food Chem. 302(1), 125-141. Doi: 10.1016/j.foodchem.2019.125141

Ramadan, M.F. 2011. Bioactive phytochemicals, nutritional value, and functional properties of cape gooseberry (Physalis peruviana): An overview. Food Res. Int. 44(7), 1830-1836. Doi: 10.1016/j.foodres.2010.12.042

Ramadan, M.F., N.A. Hassan, R.M. Elsanhoty, and M.Z. Sitohy. 2013. Goldenberry (Physalis peruviana) juice rich in health-beneficial compounds suppresses high-cholesterol diet-induced hypercholesterolemia in rats. J. Food Biochem. 37(6), 708-722. Doi: 10.1111/j.1745-4514.2012.00669.x

Ramírez-Nieto, N., Y. Baena, and C. Osorio. 2019. Caracterización fisicoquímica de emulsiones aceite/ agua a partir de uchuva (Physalis peruviana) como ingrediente para la industria alimenticia. Inf. Tecnol. 30(3), 147156. Doi: 10.4067/S0718-07642019000300147

Sánchez, E., F.L. García, L. Suescún, M. Gómez, and V.M. Núñez. 2011. Producción de plantas genéticamente puras de uchuva. Cámara de Comercio de Bogotá, Bogota.

Sánchez, E.P., F.G. Mayorga, A.A. Navas, L.F. Gómez, and V.M. Núñez. 2016. Corpoica Dorada: variedad de uchuva para Boyacá, Cundinamarca y Antioquia. Corporación Colombiana de Investigación Agropecuaria (Agrosavia), Mosquera, Colombia.

Singh, D.B., S. Lal, N. Ahmed, O.C. Sharma, A.A. Pal, and A. Mirza. 2013. Diversity assessment in cape gooseberry (Physalis peruviana L.) genotypes. Madras Agric. J. 100(4/6), 273-276.

Vignoni, L.A., R.M. Césari, M. Forte, and M.L. Mirábile, 2006. Determinación de indice de color en ajo picado. Inf. Tecnol. 17(6), 63-67. Doi: 10.4067/ S0718-07642006000600011

Yazdanpour, F., A. Khadivi, and A. Etemadi-Khah. 2018. Phenotypic characterization of black raspberry to select the promising genotypes. Sci. Hortic. 235, 95-105. Doi: 10.1016/j.scienta.2018.02.071 